\title{
Bending Properties of Graphene Reinforced Aluminium Matrix Composite Produced by Casting Process
}

\author{
Okan Aydın ${ }^{1}$, Aziz Kocaveli ${ }^{2}$, Özkan KESEN ${ }^{1}$, Selim TEMEL ${ }^{1}$, Özen Gürsoy ${ }^{3}$ and Derya Dispinar ${ }^{1,4 *}$ \\ ${ }^{1}$ Istanbul Technical University, Metallurgical and Materials Engineering, Turkey \\ ${ }^{2}$ Kar Magnesium Smelter, Eskisehir, Turkey \\ ${ }^{3}$ Padova University, Department of Management Engineering, Italy \\ ${ }^{4}$ Center of Critical and Functional Materials Technology, Turkey
}

*Corresponding author: Derya Dispinar, Center of Critical and Functional Materials

Technology, ITU, Istanbul, Turkey.

Received Date: May 21, 2020

Published Date: June 09, 2020

\begin{abstract}
The use of graphene as reinforcement for many materials has become popular due to the enhanced properties it has. In this work, different casting methods were aimed to be used in order to produce graphene reinforced aluminum matrix composites. Sand casting, lost foam casting, die casting and squeeze casting methods were used. Graphene was added as layers and also in aluminum foils for incorporation of the reinforcer to the matrix. It was found that squeeze casting was the best method for the production of composite. Bending strength was increased $25-50 \%$ for $0.1 \mathrm{wt} \%$ graphene added A356 alloy.
\end{abstract}

Keywords: Aluminum; Graphene; Composite; Casting; Bending

\section{Introduction}

The term composite is defined by combining two materials at the macro level in order to enhance the best properties of two or more same or different groups of materials in a broad sense. In other words, they can be called materials consisting of different kinds of materials or phases which are combined with each other in order to obtain superior properties by improving each other's weakness.

It is possible to classify composite materials in two classes according to the shapes of the constituent materials and components [1].

a) According to the type of matrix material;
- $\quad$ Plastic Matrix Composite

- $\quad$ Metallic Matrix Composite

- $\quad$ Ceramic Matrix Composites

b) According to the structure components;

- $\quad$ Particle Reinforced Composites

- $\quad$ Fiber Reinforced Composites

- $\quad$ Layered Composites

- $\quad$ Filled Composites

3XX series aluminum cast alloys contain silicon as the main 
alloying element, are widely used in industry. With the addition of silicon to the aluminum, fluidity, weldability, mechanical properties are increased, as well as the ability to perform special processes such as heat treatment and modification are positively affected. Silicon content of the cast alloys is $25 \%$ maximum if the alloy is produced by powder metallurgy, the amount of silicon can be up to $50 \%$ by weight [2].

Graphene was first introduced in 1994 by Boehm [3] where the properties are summarized in Table 1.

Table 1: General Properties of Single Layer Graphene [3].

\begin{tabular}{|c|c|}
\hline Properties & Value \\
\hline Hybrid Shape & sp $^{2}$ \\
\hline Number of Layers & Monolayer \\
\hline Crystal Structure & Two \\
\hline Dimension & 99 \\
\hline Degree of Purity (\%) & $\sim 0.3$ \\
\hline Mass (Bulk) Density $\left(\mathrm{g} / \mathrm{cm}^{3}\right)$ & 2.25 \\
\hline True Density $\left(\mathrm{g} / \mathrm{cm}^{3}\right)$ & $\sim 1-2$ \\
\hline Thickness $(\mathrm{nm})$ & 2600 \\
\hline Surface Area $\left(\mathrm{m}^{2} / \mathrm{g}\right)$ & $-75+200{ }^{\circ} \mathrm{C}$ \\
\hline High Temperature Resistance & $4840-5300$ \\
\hline Thermal Conductivity $\left(\mathrm{WK}{ }^{-1} / \mathrm{m}\right)$ & $\sim 2.5 \times 105$ \\
\hline Electro Mobility $\left[\mathrm{cm}^{2} /(\mathrm{V} \cdot \mathrm{s})\right]$ & $\sim 1$ \\
\hline Elastic Modulus $(\mathrm{Tpa})$ & \\
\hline
\end{tabular}

The studies and the results [3-18] obtained for the production of graphite reinforced Al composites between the years 2010-2015 are summarized in the Table2. As can be seen, most commonly used

method for the production of graphene reinforced composites were powder metallurgy.

Table 2: Studies on GNT/Al and Mechanical Properties of Produced Composites.

\begin{tabular}{|c|c|c|c|c|}
\hline $\begin{array}{l}\text { Chemical Composition } \\
(\% \mathrm{w})\end{array}$ & Production Method & Hardness (HV) & Maximum Tensile Strength (MPa) & Reference \\
\hline \multirow{2}{*}{$\% 1$ GNT-Al6061 } & \multirow{2}{*}{$\begin{array}{l}\text { Powder Metallurgy - Mechanical } \\
\text { Alloying }\end{array}$} & \multirow{2}{*}{-} & Al6061: $350-400$ & \multirow{2}{*}{ [4] } \\
\hline & & & \%1 GNT-Al6061: 760-800 & \\
\hline \multirow{2}{*}{$\begin{array}{l}\text { \%0.1 GNT-Al (Valimet } \\
\text { H-10) }\end{array}$} & \multirow{2}{*}{$\begin{array}{l}\text { Powder Metallurgy + Hot Isostatic } \\
\text { Press-Extrusion }\end{array}$} & Valimet H-10 Al: 76 & Valimet H-10: 330 & \multirow{2}{*}{ [5] } \\
\hline & & $\% 0.1$ GNT-Al: 84 & $\% 0.1$ GNT - Al: 275 & \\
\hline \multirow{2}{*}{ \%0.3 GNT-Al (Purity \%99) } & \multirow{2}{*}{ Powder Metallurgy + Hot Extrusion } & \multirow{2}{*}{-} & Base Al: 154 & \multirow{2}{*}[6]{} \\
\hline & & & $\% 0.3$ GNT - Al: 249 & \\
\hline \multirow{2}{*}{ \%0.3 GNT-Al (Purity \%99) } & \multirow{2}{*}{ Powder Metallurgy + Hot Extrusion } & Pure Al: 76 & Base Al: 252 & \multirow{2}{*}{ [7] } \\
\hline & & \%0.3 GNT-Al: 85 & $\% 0.3 \mathrm{GNT}-\mathrm{Al}: 280$ & \\
\hline \multirow{4}{*}{$\% 0.25-0.50-1$ GNT-Al } & \multirow{4}{*}{ Powder Metallurgy } & $\% 0$ GNT-Al: 40 & \multirow{4}{*}{-} & \multirow{4}{*}[8]{} \\
\hline & & \%0.25 GNT-Al: 73 & & \\
\hline & & $\% 0.5$ GNT-Al:85 & & \\
\hline & & \%1 GNT-Al: 94 & & \\
\hline \multirow{3}{*}{$\% 0.15-0.5$ GNT-Al } & \multirow{3}{*}{$\begin{array}{l}\text { Powder Metallurgy - Hot Isostatic } \\
\text { Press - Hot Extrusion }\end{array}$} & \multirow{3}{*}{-} & Base $\mathrm{Al}: 210$ & \multirow{3}{*}{ [9] } \\
\hline & & & $\% 0.15$ GNT-Al: 250 & \\
\hline & & & $\% 0.5$ GNT-Al: 315 & \\
\hline \multirow{5}{*}{$\% 0.50-1-1.5-2$ GNT-Al } & \multirow{5}{*}{ Powder Metallurgy } & \multirow{5}{*}{-} & Base Al:150 & \multirow{5}{*}[10]{} \\
\hline & & & $\% 0.5$ GNT-Al: 165 & \\
\hline & & & $\% 1$ GNT-Al: 250 & \\
\hline & & & \%1.5 GNT-Al: 212 & \\
\hline & & & $\% 2$ GNT-Al: 160 & \\
\hline
\end{tabular}




\begin{tabular}{|c|c|c|c|c|}
\hline $\begin{array}{c}\text { (\%1-3 GNT)-(\%10-15-20 } \\
\text { Al2O3)-Al }\end{array}$ & Powder Metallurgy & $155-400$ & - & [11] \\
\hline \multirow{4}{*}{$\begin{array}{c}\% 0.33-0.55-0.77 \text { GNT - } \\
\text { Al7050 }\end{array}$} & \multirow{4}{*}{ Stir Casting } & Al7050: 90 & Al7050: 150 & \multirow{4}{*}[12]{} \\
\hline & & $\% 0.33$ GNT - Al7050: 60 & $\% 0.33$ GNT - Al7050: 145 & \\
\hline & & $\% 0.55$ GNT - Al7050: 53 & $\% 0.55$ GNT - Al7050: 55 & \\
\hline & & $\% 0.77$ GNT - Al7050: 49 & \%0.77 GNT - Al7050: 47 & \\
\hline
\end{tabular}

In this work, the aim was targeted to use casting methods to produce graphene reinforced aluminum matrix composites.

\section{Experimental}

$10 \mathrm{~kg}$ of A356 aluminum alloy charge was melted at $750^{\circ} \mathrm{C}$ in resistance furnace in $\mathrm{SiC}$ crucible. Moulds were prepared as lost foam, sand cavity and permanent moulds in the dimension of 120 $\mathrm{mm}$ length, $20 \mathrm{~mm}$ wide and $20 \mathrm{~mm}$ thickness in the shape of rectangular bars.

For the casting trials, two methods were used to add graphene to the cast piece. In the first method, graphene was placed in aluminum foil which was placed vertically in the mold cavity and the melt was poured. In the second method, graphene was added to the surface of the melt during pouring. For the lost foam castings, the graphene was added as layers in between the foams, and then the melt was poured. Thixoforging was also applied to the cast piece which was produced by casting and then heating the graphene reinforced sample to $630^{\circ} \mathrm{C}$, held for 20 minutes and then forged under 220 bar pressure. For squeeze casting, after the melt was poured into the mould cavity together with graphene, the melt was pressurized at 150 bar in the mould under 30 ton presses. All these methods were investigated in order to achieve higher wettability and homogeneous distribution of graphene into the matrix.

Samples were characterized by metallographic, SEM, EDS and CT scan analyzes. 3-point bending test was carried out for mechanical property determination.

\section{Results}

SEM images of the graphene found in the matrix are given in Figure 1. For many of the trials, particularly when aluminum foils were used, the graphene appeared to stay in between the foils and foil was not melted and graphene was not distributed into the matrix.

When thixoforging and squeeze casting was used, more sound and homogeneous structure was observed. The CT scan images of these samples are given in Figure 2. For the rest of the casting trials particularly lost foam and sand casting, highly porous cast parts with agglomerated graphene were observed.

The best composite production was achieved when squeeze casting was used. Three-point bending tests are given in Figure 3a. The dark data represents the alloy without any graphene addition and the light blues are the composites. Weibull analysis of the findings is given in Figure $3 \mathrm{~b}$. As can be seen, the scatter of the results is given by Weibull modulus where it is 6.48 and 3.69 for stress and displacement, respectively. The characteristic values were recorded from Weibull analysis and it was found that stress was $26,04 \mathrm{MPa}$ and displacement was $5,84 \mathrm{~mm}$. For the base alloy, these values correspond to $20.7 \mathrm{MPa}$ and $3.46 \mathrm{~mm}$. According to these findings, by graphene addition, the stress was increased by $25.7 \%$ and displacement was enhanced by $68 \%$. However, it is important to note that the bending results show a scatter which was based on the distribution of graphene into the matrix.
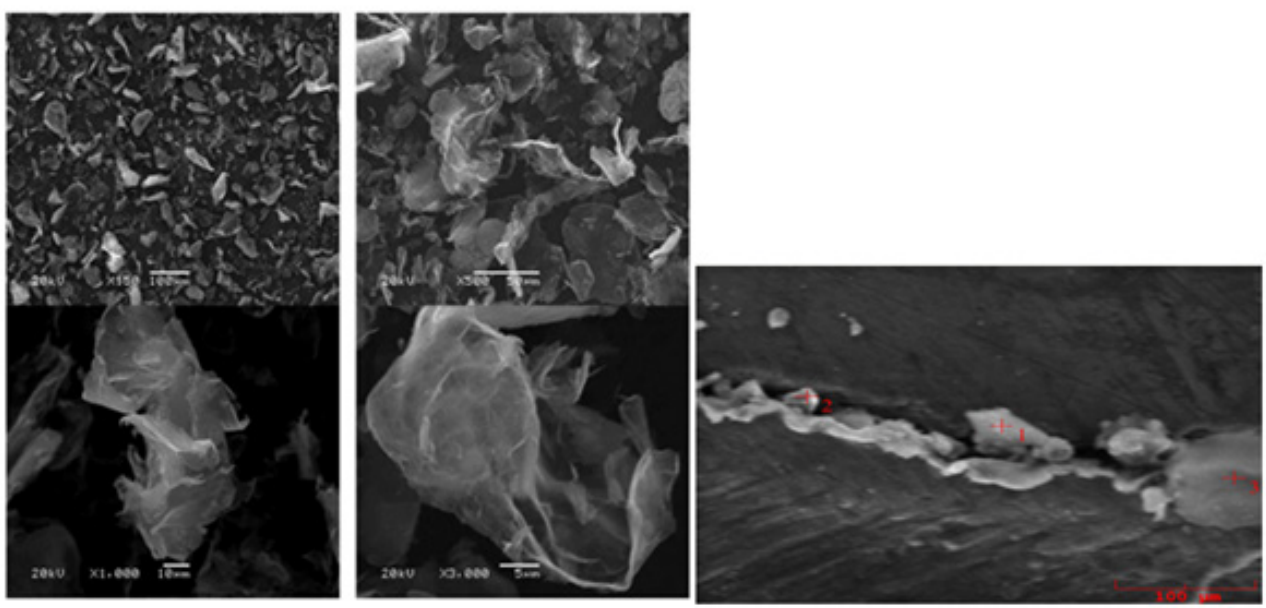

Figure 1: SEM images of graphene. 


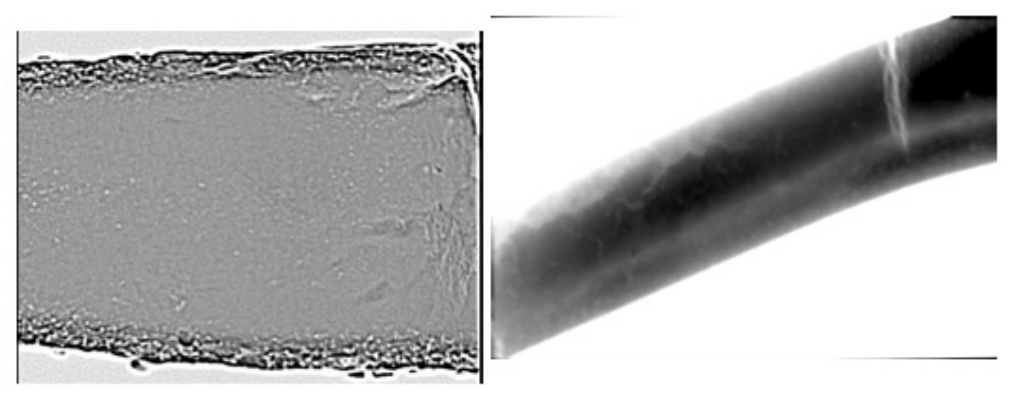

(a)

(b)

Figure 2: CT Scan image of the sample produced (a) top view (b) side view after bending test.

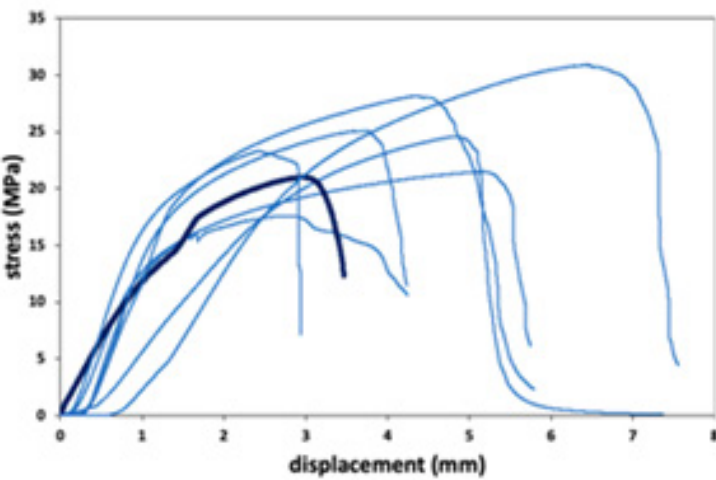

(a)

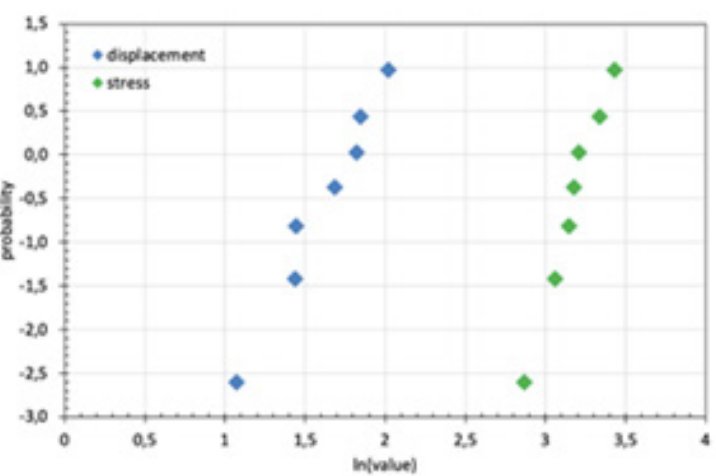

(b)

Figure 3: (a)Three-Point Bending Test Results, (b) Weibull analysis.

\section{Conclusion}

Production of graphene reinforced A356 alloy was quite challenging mainly due to the density difference and wettability of graphene. Different casting techniques were used to achieve good distribution of graphene into the matrix. Squeeze casting was found to be successful. The bending stress and displacement were enhanced by $25 \%$ by graphene addition to 356 alloys. The mechanical properties were scattered to do the inhomogeneous distribution of graphene and formation of porosity due to agglomeration.

\section{Acknowledgement}

This work was supported by Research Fund of the Istanbul Technical University. Project Number MOA-2019-42309.

\section{Conflict of Interest}

No conflict of interest.

\section{References}

1. I Polmear, D St John, JF Nie, M Qian (2017) Light alloys: metallurgy of the light metals. Butterworth-Heinemann.

2. GE Totten, DS MacKenzie (2003) Handbook of Aluminum: Volume 2: Alloy Production and Materials Manufacturing, volume 2, CRC press.
3. MC Şenel, M Gürbüz, E Koc (2018) Fabrication and characterization of synergistic Al-SiC-GNPs hybrid composites. Compos Part B Eng 154: 1-9.

4. M Bastwros, GY Kim, C Zhu, K Zhang, S Wang, et al. (2014) Effect of ball milling on graphene reinforced Al6061 composite fabricated by semisolid sintering. Compos Part B Eng 60: 111-118.

5. SF Bartolucci, J Paras, MA Rafiee, J Rafiee, S Lee, et al. (2011) Graphenealuminum nanocomposites. Mater Sci Eng A 528(27): 7933-7937.

6. J Wang, Z Li, G Fan, H Pan, Z Chen, et al. (2012) Reinforcement with graphene nanosheets in aluminum matrix composites. Scr Mater 66(8): 594-597.

7. M Rashad, F Pan, A Tang, M Asif (2014) Effect of graphene nanoplatelets addition on mechanical properties of pure aluminum using a semipowder method. Prog Nat Sci Mater Int 24(2): 101-108.

8. R Pérez-Bustamante, D Bolaños-Morales, J Bonilla-Martínez, I EstradaGuel, R Martínez-Sánchez (2014) Microstructural and hardness behavior of graphene-nanoplatelets/aluminum composites synthesized by mechanical alloying. J Alloys Compd 615: S578-S582.

9. SJ Yan, SL Dai, XY Zhang, C Yang, QH Hong, et al. (2014) Investigating aluminum alloy reinforced by graphene nanoflakes. Mater Sci Eng A 612: 440-444.

10. JL Li, YC Xiong, XD Wang, SJ Yan, C Yang, et al. (2015) Microstructure and tensile properties of bulk nanostructured aluminum/graphene composites prepared via cryomilling. Mater Sci Eng A 626: 400-405.

11. G Iacob, VG Ghica, M Buzatu, T Buzatu, MI Petrescu (2015) Studies on wear rate and micro-hardness of the $\mathrm{Al} / \mathrm{Al} 203 / \mathrm{Gr}$ hybrid composites produced via powder metallurgy. Compos Part B Eng 69: 603-611. 
12. S Venkatesan, MA Xavior (2000) Mechanical behaviour of Aluminium metal matrix composite reinforced with graphene particulate by stir casting method. J Chem Pharm Sci 10: 55.

13. U Aybarc, H Yavuz, D Dispinar, MO Seydibeyoglu (2019) The use of stirring methods for the production of SiC-reinforced aluminum matrix composite and validation via simulation studies. Int J Met 13(1): 190200.

14. U Aybarc, D Dispinar, MO Seydibeyoglu (2018) Aluminum metal matrix composites with $\mathrm{SiC}$, Al 203 and graphene-review. Arch Foundry Eng 18(2): 5-10.

15. N Akçamlı, B Küçükelyas, C Kaykılarlı, D Uzunsoy (2019) Investigation of microstructural, mechanical and corrosion properties of graphene nanoplatelets reinforced Al matrix composites. Mater Res Express 6(11): 115627.
16. N Akçamlı, H Gökçe, D Uzunso (2016) Processing and characterization of graphene nano-platelet (GNP) reinforced aluminum matrix composites. Mater Test 58(11-12): 946-952.

17. RJH Navasingh et al. (2019) Graphene-based nano metal matrix composites: A review in Nanocarbon and its Composites. Elsevier, pp. 153-170.

18. PA Kumar, HC Madhu, A Pariyar, CS Perugu, SV Kailas, et al. (2020) Friction stir processing of squeeze cast A356 with surface compacted graphene nanoplatelets (GNPs) for the synthesis of metal matrix composites. Mater Sci Eng A 769: 138517. 